\title{
FEMINITAS DAN DEKONSTRUKSI PEREMPUAN DALAM ISLAM: STUDI KASUS PEMIKIRAN NASR HAMID ABU ZAYD
}

\author{
Asep Saepullah \\ UIN Sunan Kalijaga Yogyakarta \\ Email: asepsaepullah45@gmail.com
}

\begin{abstract}
When gender becomes a tool to analyze and detect the phenomenon of injustice between men and women in society, feminists can use gender theory to help analyze the various forms of gender discrimination that exist or may exist in various aspects of people's lives. Nasr Hamid Abu Zayd is one of the leading Muslim scientists who openly claims to be a feminist. Through his ideas, Nasr Hamid Abu Zayd tried to dismantle the sectarian-racial hegemony by deconstructing the meaning of women in the verses of the Koran using model a contextual reading. This article intends to elaborate on Nasr Hamid Abu Zayd's ideas or concepts of gender deconstruction, only then to identify aspects of femininity and the role of women in Islam. This research method uses a qualitative approach to the type of literature review or library research, data is obtained from various literature books, articles, journals, magazines, and the results of other previous studies. This study finds that the case study on Nasr Hamid Abu Zayd's thoughts on the femininity and deconstruction of women in Islam has sparked debates in religious, social, political, and historical contexts. Therefore, Nasr Hamid Abu Zayd tried to re-interpret the verses of the Qur'an relating to the position of women in Islam.
\end{abstract}

Keywords: Decontruction, Femininity, Islam, Nasr Hamid Abud Zayd

\begin{abstract}
Abstrak
Ketika gender menjadi sebuah alat untuk menganalisis dan mendeteksi fenomena ketidakadilan antara laki-laki dan perempuan di masyarakat, maka feminis dapat menggunakan teori gender untuk membantu menganalisis berbagai bentuk diskriminasi gender yang ada atau mungkin ada dalam berbagai aspek kehidupan masyarakat. Nasr Hamid Abu Zayd salah satu tokoh ilmuan Muslim yang secara terang-terangan mengaku sebagai seorang feminis. Melalui gagasan-gagasannya, Nasr Hamid Abu Zayd berusaha membongkar hegemoni sektarian-rasialistik dengan
\end{abstract}


melakukan dekonstruksi terhadap pemaknaan perempuan dalam ayatayat al-Qur'an dengan menggunakan model pembacaan kontekstual. Artikel ini bermaksud untuk memaparkan gagasan atau konsep dekonstruksi gender Nasr Hamid Abu Zayd, baru setelah itu mengidentifikasi aspek-aspek feminitas dan peran perempuan dalam Islam. Metode penilitian ini menggunakan pendekatan kualitatif jenis kajian pustaka atau library research, data diperoleh dari berbagai literatur buku, artikel, jurnal, majalah, dan hasil kajian terdahulu lainnya. Kajian ini menemukan bahwa studi kasus atas pemikiran Nasr Hamid Abu Zayd tentang feminitas dan dekonstruksi perempuan dalam Islam telah memicu perdebatan di dalam konteks keagamaan, sosial, politik, dan historis. Oleh sebab itu, Nasr Hamid Abu Zayd berusaha untuk memaknai kembali ayat-ayat al-Quran yang berkaitan dengan kedudukan perempuan dalam Islam.

Kata Kunci: Dekonstruksi, Feminitas, Islam, Nasr Hamid Abu Zayd

\section{Pendahuluan}

Perempuan dalam catatan sejarah, selalu identik dengan penindasan. Bahkan sebelum Islam lahir, di masa silam, di berbagai benua, negara, bahkan belahan dunia, baik dalam ranah agama maupun non-agama, perempuan selalu di tempatkan dalam posisi yang rendah, bahkan nyaris setara dengan hewan dan benda-benda yang bisa diperlakukan semena-mena sesuai dengan keinginan pemiliknya. Mereka bisa dijual kapan saja, kepada siapa saja, dengan harga berapa saja. Bahkan mereka sering kali dipaksa untuk melayani nafsu birahi (biologis) tuannya.

Sikap arogansi yang kaum laki-laki tunjukkan, cenderung tidak mau mengakui realita bahwa perempuan memiliki peran yang sangat vital, yakni sebagai pembuat kehidupan, sama halnya dengan peran laki-laki, baik dalam masyarakat Islam maupun di setiap masyarakat maupun kebudayaan. Sikap arogansi tersebut secara tidak langsung telah melahirkan sebuah penindasan terhadap perempuan dalam berbagai bentuk dan dengan berbagai media. Sementara semua aturan dalam Islam, terutama yang tertuang dalam nash tersebut harus menjadi worldview (pandangan hidup) dan pijakan dalam beragama. Namun, dewasa ini muncul pro-kontra 
antara ulama klasik dan kontemporer, terutama dalam konteks penafsiran perspektif gender (tafsir gender) yang melingkupi latar belakang kehidupan para penafsirnya. ${ }^{1}$ Dari sinilah mulanya trend tafsir gender berkembang, dengan mengkaji persoalan-persoalam yang dianggap memarjinalkan dan mendiskreditkan posisi perempuan, terutama dalam Islam.

Islam sendiri hadir sebagai solusi di tengah-tengah penindasan dan ketidakadilan yang dialami perempuan. Secara perlahan, Islam mampu mengangkat derajat kaum perempuan dan menghapus struktur patriarki pada masa jahiliah dengan memberikan hak yang sama antara laki-laki dan perempuan. ${ }^{2}$ Bahkan, Rasulullah memberikan hak-hak istimewa kepada kaum perempuan seperti memberikan jaminan dan kedudukan yang sama dengan laki-laki di hadapan Allah dari segala aspek termasuk aspek kepemimpinan dan politik (QS. At-Taubah: 71-72). ${ }^{3}$ Namun, kondisi tersebut tidak dapat bertahan lama. Setelah zaman Rasulullah dan setelah pemerintahan Khulafa ar-Rasyidin, sistem pemerintahan berubah kembali menjadi monarki yang menganut sistem hubungan terpisah antara sultan dan rakyat atau raja dan rakyat. Dalam sistem monarki tersebut terlihat ada satu sistem budaya yang diadopsi, yaitu budaya perseliran (memperbanyak istri simpanan). Dari situlah secara perlahan peran perempuan kembali terpinggirkan seperti di masa silam. Padahal di zaman Nabi, perempuan yang awalnya tidak memiliki nilai dan selalu diwariskan dari satu pemilik ke pemilik yang lain, menjadi memiliki hak dan kewajiban dalam keluarga, termasuk hak waris.

Menurut tokoh-tokoh feminis, perlu adanya rekonstruksi atau bahkan dekonstruksi terkait penafsiran ayat-ayat al-Qur'an

1 Afifah Bidayah, "Riffat Hassan dan Wacana Baru Penafsiran," KALIMAH 11, no. 2 (2013): 306.

2 M. Hajir Mutawakkil, "Keadilan Islam dalam Persoalan Gender," KALIMAH 12, no. 1 (March 5, 2014): 68, https://doi.org/10.21111/klm.v12i1.219.

${ }^{3}$ Hamka, Buya Hamka Berbicara Tentang Perempuan (Jakarta: Gema Insani, 2014), 8-9. 
tentang perempuan. Lalu, memaknai ulang ayat-ayat tersebut berdasarkan konteks historis masyarakat, seperti budaya patrilineal dan inferioritas perempuan yang menurut sebagian tokoh feminis yang sangat kental di tengah masyarakat Islam. ${ }^{4}$ Ditambah lagi dengan ditemukannya hadits-hadits yang dianggap bersifat misoginis (merendahkan perempuan) membuat para penafsir ayat-ayat gender semakin memiliki alasan yang cukup kuat untuk melakukan rekonstruksi maupun dekonstruksi. Perlu menjadi catatan juga bahwa wacana gender mulai berkembang di Indonesia sekitar tahun 80-an, dan mulai memasuki ruang lingkup keagamaan sekitar tahun 90-an, serta mulai ramai kembali sekitar 5 sampai 10 tahun belakangan ini. ${ }^{5}$

Sosok Nasr Hamid Abu Zayd (1943-2010) ${ }^{6}$ yang dikenal sebagai seorang cendekiawan muslim kontemporer yang banyak bergelut dengan berbagai model pembacaan dan pendekatan yang beragam dalam memahami teks-teks suci keagamaan, juga ikut menyumbangkan pemikirannya tentang pentingnya penggunaan hermeneutika dalam melakukan pembacaan teks. ${ }^{7}$ Termasuk pembacaannya tentang kesetaraan gender. Perihal persoalan ketertindasan kaum perempuan yang banyak dilakukan oleh kaum laki-laki, bagi Nasr telah menimbulkan relasi laki-laki dan perempuan yang pincang dan bersifat subordinatif; yang satu menguasai yang lain dengan satu perasaan yang satu tinggi dan mulia dan yang lain rendah dan hina, sehingga yang satu boleh

${ }^{4}$ Bidayah, "Riffat Hassan dan Wacana Baru Penafsiran," 306.

5 Andik Wahyun Muqoyyidin, "Wacana Kesetaraan Gender: Pemikiran Islam Kontemporer Tentang Gerakan Feminisme Islam," Jurnal Al-Ulum 13, no. 2 (2013): 492.

${ }^{6}$ Selain seorang cendikiawan, Nasr Hamid Abu Zayd juga dikenal sebagai seorang pemikir asal Mesir. Lihat Muzayyin Bdws, "Kritik Terhadap Konsep Tanzil Nasr Hamid Abu Zayd dan Implikasinya Terhadap Status Al-Qur'an," TAJDID: Jurnal Ilmu Ushuluddin 17, no. 2 (June 15, 2019): 154, https://doi.org/10.30631/tjd.v17i2.69.

7 M. Arfan Mu'ammar, Abdul Wahid Hasim dkk, Studi Islam Perspektif Insider/Outsider (Yogyakarta: IRCiSoD, 2013), 196. 
melakukan ini, sementara yang lain tidak boleh. ${ }^{8}$ Alasannya seringkali seksis dan biologis.'

Menurut Nasr Hamid Abu Zayd, diperlukan pendekatan humanis dan keadilan yang menjadi landasan dalam pengambilan keputusan terakhir. Lebih lanjut, Nasr Hamid menerangkan bahwa Allah sendiri memiliki sifat Maha Penyayang dan Maha Adil. Tidak mungkin Dia menginginkan kesewenang-wenangan, penindasan, dan otoritas oleh satu orang atau kelompok atau kepada orang atau kelompok yang lain, termasuk oleh laki-laki atas perempuan. ${ }^{10}$ Muhammad Nasr Abu Zayd dengan bukunya yang berjudul Dawair al-Khauf: Qiraah Fi Khithah al-Mar'ah, mengungkapkan ide-idenya tentang kesetaraan gender dan mencoba menjelaskan gagasangagasannya melalui metode dekonstruksi dalam memahami gender; sebuah upaya meluruskan wacana perempuan dalam Islam.

Berangkat dari persoalan-persoalan di atas, Artikel ini ingin menjelaskan tentang gagasan atau pemikiran Nasr Hamid Abu Zayd tentang peran perempuan dalam Islam dengan model pembacaan al-qiraah al-siyaqiyah (pembacaan kontekstual). Sehingga ayat-ayat al-Quran dan hadits tidak dijadikan sebagai argumen dan tameng bagi para pelaku penindasan yang selalu bersifat seksis-biologis. Oleh sebab itu apabila pemaparan di atas ditambahkan dengan teori gender, maka akan terlihat konstruk patriarki berupa hegemoni negara yang membatasi aktifitas gerak perempuan, diskriminasi gender berupa larangan perempuan keluar dan beraktifitas di luar rumah karena dianggap zina, dan akar diskriminasi berupa pemikiran-pemikiran dari para pemegang kekuasaan.

8 M. Arfan Mu'ammar, Abdul Wahid Hasim dkk, Studi Islam Perspektif Insider/Outsider (Yogyakarta: IRCiSoD, 2013), 203-204.

${ }^{9}$ Ibid., hal 204.

${ }^{10}$ Ibid., hal 212. 


\section{Metodologi Penelitian}

Adapun metodologi penelitian dalam penelitian ini penulis menggunakan metode kualitatif dengan jenis library research (studi kepustakaan). Penelitian ini lebih fokus pada gagasan-gagasan atau pemikiran-pemikiran Nasr Hamid Abu Zayd tentang feminis dan peran perempuan dalam Islam. Sumber data yang digunakan dalam penelitian ini ada dua jenis, yakni sumber primer dan sumber sekunder. Sumber primernya adalah karya asli dari Nasr Hamid Abu Zayd yang berjudul Dawair al-Khaufi: Qiraah fi Khitab akMar'ah.11 Sedangkan sumber sekunder adalah dari berbagai buku, jurnal, artikel, hasil penelitian dan berbagai sumber literatur lainnya yang mengkaji dalam ruang lingkup feminis, gender, perempuan dalam Islam. Data yang sudah terkumpul kemudian diolah dan dianalisis secara deskriptif dengan pendekatan historis-filosofis, mengingat dalam penelitian ini banyak berkaitan dengan pemikiran, tokoh dan sejarah. Dengan langkah tersebut, tentu penulis berharap dapat menyajikan secara otentik dan mendalam terkait feminitas dan dekonstruksi perempuan dalam Islam: studi kasus pemikiran Nasr Hamid Abu Zayd.

\section{Pembahasan}

\section{Persoalan-persoalan Gender, Seks, dan Seksualitas}

Perlu kiranya dijelaskan terlebih dahulu mengenai pemaknaan gender ${ }^{12}$ itu sendiri. Di antara pemaknaan tersebut ialah, gender sebagai sebuah istilah baru, gender sebagai suatu fenomena, gender sebagai sebuah alat analisis, gender sebagai sebuah perspektif, gender sebagai sebuah kesadaran, dan gender sebagai sebuah persoalan. Perbedaan pemaknaan ini melahirkan

11 Telah dialih bahasakan oleh Moch. Nur Ichwan dan Moch. Syamsul Hadi menjadi “Dekonstruksi Gender Kritik Wacana Perempuan dalam Islam”.

12 Muqoyyidin, "Wacana Kesetaraan Gender: Pemikiran Islam Kontemporer Tentang Gerakan Feminisme Islam," 496. 
wacana pemisahan fungsi dan tanggung jawab antara laki-laki dan perempuan. $^{13}$

Gender sebagai alat analisis atau tool of analysis berfungsi untuk menganalisis fenomena sosial yang terkait dengan isu gender. Sementara itu, konstruksi sosial tentang laki-laki dan perempuan di masyarakat merupakan bentuk dan akar dari diskriminasi. Jadi, gender adalah konstruksi sosial, bukan (sesuatu yang ditentukan secara) biologis ${ }^{14}$; perempuan adalah dibentuk bukan dilahirkan. Oleh sebab itu, perbedaan peran dan kesempatan antara laki-laki dan perempuan dalam keluarga dan masyarakat sebagai hasil konstruksi sosial yang dapat berubah atau diubah sesuai kebutuhan zaman.

Berbicara mengenai perbedaan antara perempuan dan lakilaki, baik terkait status, sifat, peran, tanggung jawab, pembagian kerja dan lain sebagainya, merupakan bagian dari isu kekinian yang berkaitan dengan konstruksi sosial. Fenomena tersebut telah menyebabkan ketidakadilan dan diskriminasi gender. Sementara gender juga merujuk pada sejumlah gagasan dan harapan yang berkembang di masyarakat tentang laki-laki dan perempuan. Berikut bagan scanning yang terkait dengan perbedaan antara gender dan seks;

\begin{tabular}{|l|l|l|}
\hline Karakteristik & Seks/Jenis Kelamin & Gender \\
\hline Sumber & $\begin{array}{l}\text { Tuhan/Alamiyah } \rightarrow \\
\text { Given }\end{array}$ & $\begin{array}{l}\text { Konstruksi } \\
\text { manusia/sosial } \rightarrow \\
\text { Proses eksternalisasi }\end{array}$ \\
\hline Aspek & $\begin{array}{l}\text { Biologis (alat } \\
\text { reproduksi) }\end{array}$ & Budaya/Kultur \\
\hline
\end{tabular}

13 Rusdi Zubeir, "Gender dalam Perspektif Islam," An Nisa'a 7, no. 2 (2012): 103.

14 Rustan Efendy, "Kesetaraan Gender Dalam Pendidikan," Jurnal AlMaiyyah 07, no. 2 (2014): 143. 


\begin{tabular}{|l|l|l|}
\hline Sifat/Ciri & $\begin{array}{l}\text { Kodrat, } \\
\text { Permanen/abadi, } \\
\text { Universal, tidak } \\
\text { dapat dipertukarkan }\end{array}$ & $\begin{array}{l}\text { Bentukan sosial, } \\
\text { changeable, lokal, } \\
\text { dapat dipertukarkan }\end{array}$ \\
\hline Implikasi & $\begin{array}{l}\text { Kesetaraan, saling } \\
\text { melengkapi }\end{array}$ & $\begin{array}{l}\text { Bipolaritas dan } \\
\text { perbedaan gender }\end{array}$ \\
\hline
\end{tabular}

Persoalan lainnya yang berkaitan dengan gender dan seks ialah persoalan seksualitas. Secara sederhana, seksualitas adalah konstruksi sosial tentang pengetahuan, norma, dan perilaku serta subjektivitas yang berkaitan dengan seks atau hal-hal yang berkaitan dengan seks atau hal-hal yang dianggap menarik dengan hasrat atau atau rangsangan. Sementara itu, bagi Michel Foucault, seksualitas mencakup nilai atau norma, aturan-aturan yang memberikan status dan peran, yang membatasi dan perilaku tindakan yang berkaitan dengan seks.

Kaitannya dengan Islam ialah terletak pada analisis gender dalam ilmu tafsir, yang melahirkan sikap mainstream, androsentris, seksis, dan patriarki. Superioritas laki-laki tercerminkan pada definisi manusia pertama dalam kebanyakan tafsir dipahami sebagai Adam, yang lebih sering dipahami sebagai laki-laki bapak dari seluruh manusia. Sementara Hawa adalah perempuan yang diciptakan dari tulang rusuk Adam, bahkan dari tulang rusuk yang paling bengkok. Meskipun demikian, banyak pula pemikir Islam kontemporer yang lebih memilih mengartikan Adam sebagai jenis manusia dan bukan jenis kelamin laki-laki dan bukan jenis kelamin laki-laki dari manusia, namun pendapat ini tidak atau belum populer dibandingkan dengan pendapat pertama yang sudah menjadi mainstream (arus utama) dalam masyarakat Islam.

Pada kenyataannya, perempuan selalu menjadi objek gender kedua setelah laki-laki. Sehingga akal atau intelektualitas dan pengetahuan perempuan lebih rendah dibanding laki-laki. Misalnya dalam tafsir Al-Qurtubi, laki-laki memiliki kelebihan akal, 
managerial, kejiwaan, dan naluri, yang tidak dimiliki oleh perempuan. Naluri laki-laki diyakini didominasi oleh unsur panas dan kering yang merupakan sumber kekuatan. Sementara naluri perempuan didominasi unsur basah dan dingin yang merupakan sumber kelembutan dan kelemahan. Sementara tafsir Zamakhsari (mu'tazilah) yang dikenal dengan rasionalitasnya mengatakan bahwa laki-laki memiliki berbagai kelebihan diantaranya dalam hal akal, ketegasan, kekuatan tekad, kekuatan fisik, dan karena itulah, laki-laki menjadi para Nabi, ulama, kepala negara, dan imam. Namun, bukan berarti penafsiran atau tafsir modern dan kontemporer tidak otomatis inklusif gender.

Konstruksi terhadap status perempuan yang lebih rendah ini berimplikasi pada pembagian peran yang hirarkis. Laki-laki dengan berbagai kelebihan yang "dipandang kodrati" (padahal sebenarnya konstruksi gender) dengan demikian dianggap lebih tepat sebagai pemimpin atau Imam. Sementara perempuan dengan berbagai "kekurangan dan kelemahannya" (konstruksi gender) menjadi pihak yang dipimpin dan menjadi ma'mum yang harus mengikuti dan ta'at pada sang Imam. Isu-isu gender dalam tafsir yang menjadi persoalan diantaranya, konsep penciptaan perempuan, status ontologis dan ontonomi perempuan, ketaaran isteri pada suami, poligami, konsep wali, konsep mahram, kepemimpinan perempuan dalam wilayah domestik, ${ }^{15}$ publik (termasuk politik) maupun dalam hal ibadah, dan lain sebagainya. Sehingga melahirkan budaya patriarki yang merupakan sumber dari segala ketidaksetaraan gender. ${ }^{16}$

Dialektika antara ilmu tafsir dan konstruksi gender diperlukan untuk mengingklusikan secara setara pengalaman dan suara perempuan, perspektif gender dan pada saat yang sama mempertimbangkan aspek tekstualitas, konstruksi gramatikal, teks,

15 Ida Novianti, "Dilema Kepemimpinan Perempuan Dalam," YinYang 3, no. 2 (2008): 5 .

16 Muhammad Husni, "Kekerasan Terhadap Perempuan: Analisis Gender Dalam Taoisme Islam” 10, no. 2 (2016): 7. 
dan konteks. Pemikir Islam kontemporer Nasr Hamid Abu Zayd, menjadi salah satu tokoh yang cukup aktif dalam mendekonstruksi wacana perempuan dalam Islam. Menurutnya, wacana tentang perempuan yang diproduksi di dunia Arab kontemporer secara global merupakan wacana yang bersifat sektarian-realistik, yakni membicarakan keabsolutan perempuan dan menempatkannya dalam hubungan-komparatif dengan keabsolutan laki-laki. ${ }^{17}$ Sehingga ketika suatu pola di antara dua pihak (laki-laki dan perempuan) saling berhadapan atau bertentangan, maka yang terjadi adalah salah satu dari kedua pihak tersebut harus patuh, takluk, dan tunduk kepada pihak yang lebih otoriter. Wacana inilah yang ingin didekonstruksi oleh Nasr Hamid Abu Zayd.

Sebetulnya persoalan gender merupakan masalah yang sangat mendasar, luas dan serius dalam Islam. Kajian-kajian mengenai feminitas dan kesetaraan gender menjadi kajian yang tidak akan pernah habis untuk dibahas. Belum lagi apabila para pemuka agama menafsirkan ayat-ayat al-Qur'an secara berbeda satu sama lain. Oleh sebab itu, penting kiranya membahas secara mendalam dan kritis terkait persoalan-persoalan feminitas dan gender dalam Islam perspektif pemikiran tokoh, termasuk dalam studi kasus pemikiran Nasr Hamid Abu Zayd.

Sementara budaya patriarki yang menghegemoni sebagai akar dari segala bentuk intimidasi, penindasan, dan ketidakadilan telah melahirkan sebuah kesadaran baru yang disebut ideologi gender. Hal tersebut diwarnai oleh pandangan bahwa kedudukan laki-laki lebih tinggi di atas perempuan, yang diperkuat melalui pemahaman dan otoritas agama serta tradisi. ${ }^{18}$ Sehingga muncullah sebuah aliran, pemikiran, teori, pandangan, atau kesadaran yang melihat

17 Nasr Hamid Abu Zayd, Dekonstruksi Gender: Kritik Wacana Perempuan Dalam Islam (Yogyakarta: Samha, 2003), 3.

18 Inayah Rohmaniyah, Gender dan Kontruksi Patriarki dalam Tafsir Agama (UIN Sunan Kalijaga Yogyakarta: Suka Press, 2020), 22. 
bahwa terdapat diskriminasi dan ketidakadilan terhadap kedudukan perempuan di dalam masyarakat yang disebut feminisme. ${ }^{19}$

Komunitas feminin atau disebut feminitas telah begitu aktif dalam menyuarakan kesetaraan antara laki-laki dan perempuan. Feminisme yang lahir di barat pada abad ke-19 dan 20 menjadi role model bagi pembebasan perempuan di banyak negara yang penduduknya Muslim. Hal tersebut bermula ketika para intelektual Mesir belajar ke Eropa, dan mereka mulai mengembangkan model pembebasan dengan istilah "Tabrir al-Mar'ah" (pembebasan perempuan). Gerakan ini semakin berkembang manakala masyarakat mulai menyadari ketertindasan dan penindasan yang diakibatkan oleh kolonialisme dan modernisme. ${ }^{20}$

Tidak sedikit dari para pelaku diskriminasi yang berujung pada tindakan penindasan dan ketidakadilan terhadap kaum perempuan yang dilatarbelakangi hanya karena mereka berjenis kelamin perempuan, dan masih berlanjut hingga zaman kontemporer saat ini. Pelakunya menggunakan berbagai macam cara, alasan dan argumentasi untuk mendapatkan legitimasi terhadap kejahatan yang mereka lakukan. Bahkan tidak sedikit ayat al-Quran dan hadits-hadits Nabi dijadikan sebagai tameng dan senjata untuk melakukan penindasan terhadap perempuan. Maka tidak elok rasanya, apabila di antara laki-laki dan perempuan ada yang mengklaim superior dan ada juga yang mengklaim inferior (the self/ the other). ${ }^{21}$

${ }^{19}$ Rohmaniyah, 30.

20 Ariana Suryorini, "Menelaah Feminisme dalam Islam," Sawwa: Jurnal Studi Gender 7, no. 2 (May 15, 2012): 22, https://doi.org/10.21580/sa.v7i2.647.

21 Yayuk Fauziyah, "Menyingkap Kuasa Maskulinitas di Balik Tabir Feminitas Wanita Jawa," Ulumuna 12, no. 1 (November 5, 2017): 183-200, https://doi.org/10.20414/ujis.v12i1.397. 


\section{Sketsa Biografi dan Perjalanan Intelektual Nasr Hamid Abu Zayd}

Dalam sebuah seminar, ada hal yang menarik ketika Nasr Hamid Abu Zayd menolak disebut feminis Islam atau Islamic feminist dan lebih suka disebut sebagai feminis Muslim. Alasannya, karena dia tidak mengembangkan gagasan-gagasan feminismenya dari tradisi Islam, tapi dari pengalaman dan nilai-nilai humanisme secara umum. ${ }^{22}$ Maka lebih tepat apabila disebut sebagai seorang feminis Muslim.

Nasr Hamid Abu Zayd lahir di sebuah desa yang bernama Thantha, ibu kota Provinsi al-Gharbiyah, Mesir pada 1 Juli $1943^{23}$ dari keluarga taat beragama. Hidup dalam lingkungan Kelurga yang taat beragama, Zayd kecil pada usial 8 tahun sudah mampu menghafal al-Quran. Setelah lulus di sekolah Teknik Thantha tahun 1960, Nasr Hamid Abu Zayd melanjutkan jenjang pendidikannya dari mulai S1 sampai S3 di jurusan Sastra Arab, Fakultas Sastra, Universitas Cairo (1968-1981) dan mengabdi juga sebagai dosen di Universitas tersebut pada tahun 1972.

Pada tahun 1978-1980, Nasr Hamid Abu Zayd pergi dan tinggal di Amerika selama dua tahun. Dia mendapatkan beasiswa untuk penelitian doktoralnya di Institute of Middle Eastern Studies, University of Pennsylvania, Philadelphia. Selama tinggal di Amerika inilah, kemampuan bahasa Inggris Nasr Hamid Abu Zayd baik secara lisan maupun tulisan semakin terasah dan berkembang. Perjalananan Nasr sebagai dosen yang dimulai dari Universitas Cairo, ternyata membawa dirinya untuk mencicipi pengalaman sebagai dosen tamu di Universitas Osaka, Jepang.

Kepiawaian Nasr Hamid Abu Zayd terhadap sastra dan bahasa Arab, membuat Nasr dipercaya untuk mengajar bahasa Arab di Universitas tersebut selama empat tahun (Maret 1985-Juli

22 Zayd, Dekonstruksi Gender: Kritik Wacana Perempuan dalam Islam, xii.

${ }_{23}$ M. Arfan Mu'ammar, Abdul Wahid Hasim dkk, Studi Islam Perspektif Insider/Outsider, 197. 
1989). Bahkan dia pernah dipromosikan sebagai profesor, namun ditolak karena hasil kerja dan pemikirannya dianggap kontroversial. Lalu, pemikiran-pemikirannyanya yang kontroversial tersebut, membuatnya divonis 'murtad' dan dikenal sebagai peristiwa 'Qadiyyah Nasr Hamid Abu Zayd'. Tidak sampai di situ saja, vonis 'pemurtadan' juga telah menyeret Nasr Hamid Abu Zayd hingga pengadilan banding Kairo, dan keputusan pengadilan menetapkan Nasr Hamid Abu Zayd bersalah, serta memintanya untuk menceraikan istrinya yang bernama Ebtehal. ${ }^{24}$

Akibat dari peristiwa tersebut, membuat Nasr Hamid Abu Zayd harus meninggalkan Mesir, dan memutuskan tinggal di Netherlands bersama istrinya. Vonis yang terjadi di Mesir tidak membuatnya berhenti di dunia akademik, dia justru menjadi profesor tamu studi Islam di Universitas Leiden Belanda (sejak 26 Juli 1995- 27 Desember 2000), dan ditetapkan sebagai Guru Besar di Universitas tersebut.

Salah satu fatwa yang menggelisahkan dan membuat geram Nasr Hamid Abu Zayd adalah fatwa yang dikeluarkan oleh ketua Lembaga Kajian dan Fatwa, Syekh Abd. Al-Azis bin Baz di Saudi Arabia. Dalam fatwanya berisi tentang perempuan keluar rumah atau bekerja disektor publik, dengan judul yang dianggap sangat melecehkan perempuan, 'amal al-mar'ah min a'zam wasail al-zina. ${ }^{25}$ Alasan yang selalu muncul untuk memenjara perempuan di dalam rumahnya adalah alasan yang bersifat seksis-biologis; zina atau skandal seks. Maka Nasr Hamid ingin meluruskan wacana perempuan dalam Islam dengan metode dekonstruksi gender. Gagasan-gagasan dari Nasr Hamid Abu Zayd ini juga turut digaungkan oleh para aktifis Feminis, salah satunya ialah Nawal El Saadawi. Menurut Nawal, musuh perempuan di sebagian besar negara tidak banyak berkembang karena mereka tidak dapat bebas

${ }^{24}$ M. Arfan Mu'ammar, Abdul Wahid Hasim dkk, 197.

${ }^{25}$ Fatwa tersebut dikutip oleh Nasr Hamid dari Majalah Ruz al-Yusuf, 24 Agustus 1998 (edisi 3665, tahun 73) dalam M. Arfan Mu'ammar, Abdul Wahid Hasim dkk, 204. 
di bawah sistem patriarkal, kapitalis, imperealis, dan militeris, yang menjadi jalan hidup saat ini dan yang menata dengan kekuasaan bukan dengan keadilan, tapi dengan demokrasi palsu bukan yang tidak memiliki kebebasan sejati. Maka dari sini muncullah teori konflik, yaitu segala perubahan diyakini atas konflik. Misalnya konflik adalah revolusi, ekspoitasi, kolonialisme, ketergantungan, konflik kelas dan rasial.

Sementara itu, di Barat, sosok Hegel dianggap sebagai pemikir pertama yang memberi tekanan perhatian pada konflik sebagai inti dari perubahan. Bagi Hegel, perubahan adalah dialectic, yakni hasil dari proses tesis, antitesis dan sintesis. ${ }^{26}$ Konsep ini mempengaruhi dasar teori Karl Marx yang kemudian berpengaruh kepada banyak teori perubahan dan developmentalisme saat ini. Namun banyak kritik terhadap tafsiran Marxisme nantinya. Salah satunya datang dari Antonio Gramsci. Dia menolak determinisme ekonomi dengan memberi perhatian lebih pada hegemoni dalam permasalahan melanggengkan struktur kelas dan ideologi masyarakat. ${ }^{27}$ Antonio Gramsci mempertanyakan mengapa di Barat yang lahir justru fasisme, bukan komunisme atau sosialisme. Bagi Gramsci, keyakinan ideal masyarakatlah yang akan menciptakan perubahan, itulah yang kemudian mendorong kapitalisme mengambil strategi force and concent, dan dari sinilah lahir "hegemoni". Hegemoni juga merujuk pada kedudukan ideologis satu atau lebih kelompok atau kelas dalam masyarakat sipil yang lebih tinggi dari lainnya. ${ }^{28}$ Pada hakikatnya, hegemoni memiliki konsep yang netral, yakni tidak memilih baik ataupun buruk. Gramsci sendiri menggunakannya dalam rangka perjuangan kelas dalam masyarakat, termasuk perjuangan kaum perempuan dalam hal kesetaraan. Sudah seharusnya kita mendekonstruksi

26 Mansour Fakih, Analisis Gender dan Transformasi Sosial (Yogyakarta: Pustaka Pelajar, 2013), 35.

27 Fakih, 36.

28 Nezar Patria \& Andi Arief, Antonio Gramsci: Negara dan Hegemoni (Yogyakarta: Pustaka Pelajar, 2015), 121. 
pemahaman kita terkait gender, terutama pemahaman tentang kesetaraan gender dan wacana perempuan dalam Islam. Sehingga kedudukan perempuan sama pentingnya dengan kedudukan lakilaki, dan terbebas dari hegemoni patriarki yang cenderung menindas kaum perempuan.

Nasr Hamid Abu Zayd merupakan seorang cendekiawan sekaligus ilmuwan Muslim yang sangat produktif. Hal tersebut dibuktikan dengan menulis lebih dari dua puluh sembilan karya ilmiah sejak 1964 sampai 1999, baik berbentuk buku, maupun artikel. Salah satu karyanya yang paling monumental adalah Dawair al-Kawf, Qira'ah fi Khitab al-Mar'ab (Dar el-Beidah, 1999). Pada akhirnya, Nasr Hamid Abu Zayd menghembuskan nafas terakhirnya pada hari Senin tanggal 5 Juli 2010, akibat serangan virus langka dan mematikan yang secara medis belum diketemukan cara pengobatannya saat itu.

\section{Diskursus Perempuan dalam Islam}

Fenomena keagamaan hari ini, masih memiliki wacana normatif yang bias akan kepentingan kaum laki-laki. Terutama yang berkaitan dengan relasi gender. ${ }^{29}$ Secara praktis, Islam menghendaki adanya kesetaraan gender di tengah masyarakat. Bahkan semasa Nabi Muhammad hidup, kehidupan sosial beliau dengan para pengikutnya, diakui telah menempatkan posisi perempuan menjadi lebih baik dan setara dengan laki-laki. Hegemoni struktur patriarki pada masa jahiliah, telah berhasil dibongkar oleh Islam dengan memberikan hak kepada perempuan yang pada masa sebelumnya tidak diterima oleh perempuan. Contoh sederhananya ialah tentang waris. Pada masa pra-Islam, perempuan tidak memiliki hak waris, dan menjadi aib bagi keluarga bangsawan apabila melahirkan anak perempun. Islam pun tidak setuju dan menolak struktur patriarki tersebut, dan menjanjikan

29 Mahathir Muhammad Iqbal, "Diskursus Gender dalam Pendidikan Islam," Analisis 15, no. 1 (2015): 100.

TAJDID vol. 19, No. 1, Januari - Juni 2020 | 73 
pahala apabila umatnya dapat memperlakukan anak perempuan seperti dia memperlakukan anak laki-laki.

Dalam bukunya yang berjudul Ratu-ratu Islam Yang Terlupakan, ${ }^{30}$ Fatima Mernissi mencatat banyak perempuan pada masa Nabi berhasil memegang sektor-sektor penting dalam dunia politik. Hal tersebut merupakan implikasi dari kehidupan sosial yang berbasis relasi ideal antara laki-laki dan perempuan. Namun, romantisisme ini tidak berjalan lama, setelah pemerintahan khulafa ar-rasyidin yang bersifat demokratis berakhir, sistem pemerintahan Islam berubah menjadi sistem monarkhi yang absolut. Hal tersebut makin diperparah oleh adanya legitimasi membuat hadits-hadits palsu untuk berbagai macam kepentingan. Dari mulai kepentingan ideologi, hingga kepentingan politik. Bersamaan dengan fenomena tersebut, muncul hadits-hadits yang dianggap merendahkan kaum perempuan menurut para feminis. ${ }^{31}$

Perlu menjadi perhatian juga, bahwa feminisme dalam Islam tidak menyetujui sepenuhnya terkait pandangan feminis Barat, terutama pandangan yang ingin memposisikan laki-laki sebagai lawan perempuan. Sebaliknya, justru feminisme Islam tetap berupaya untuk memperjuangkan relasi yang setara antara laki-laki dengan perempuan, yang cenderung terabaikan dalam diskursus kalangan tradisional-konservatif, yang memandang perempuan sebagai subordinat laki-laki. ${ }^{32}$

Selama ini teks-teks keagamaan ditafsirkan secara kaku serta legal-formal tanpa mempertimbangkan aspek-aspek sosio-historis teks yang melingkupinya dan bahkan telah menyebabkan tertutupnya pintu ijtihad. Hal tersebut berdampak pada kehidupan sosial yang patuh dan tunduk pada corak penafsiran dan

30 Fatima Mernissi, Ratu-Ratu Islam Yang Terlupakan (Bandung: Mizan, 1996).

31 Ahmad Baidowi, Memandang Perempuan: Bagaimana al-Quran dan Penafsir Modern Menghormati Kaum Hawa (Bandung: Marja, 2011), 44.

32 Suryorini, "Menelaah Feminisme dalam Islam," 24. 
pemahaman keagamaan masa lampau (ulama klasik), ${ }^{33}$ yang belum tentu masih relevan untuk dijalankan oleh umat hari ini. Tidak berhenti di situ saja, persoalan lainnya muncul ketika teks-teks keagamaan yang bersifat interpretatif dijadikan landasan otoritatifformalistik dalam sebuah penafsiran. ${ }^{34}$ Namun, pandangan klasik yang dianggap patriar dari aktifis feminin mendapat respons kritis dari berbagai macam kalangan. ${ }^{35}$

Feminis Muslim cukup memiliki kesadaran akan kondisi yang dialami oleh para kaum perempuan, terutama di negara berbasis Islam, bukanlah tanpa alasan. Oleh sebab itu, mereka mencoba mengkaji dan mengarahkan perhatian secara lebih mendalam kepada sumber yang menyebabkan ketimpangan terhadap perempuan. ${ }^{36}$ Islam mengajarkan manusia untuk memperhatikan konsep keseimbangan yang mengandung nilai-nilai kesetaraan (equality), keadilan, dan menolak ketidakadilan, keselarasan, keserasian, dan keutuhan bagi manusia. Ajaran Islam yang paling subtil memaknai Adi sebagai sesuatu yang proposional, yang meletakkan sesuatu pada tempatnya bukan sama banyak atau rata. $^{37}$

Bersumber pada al-Qur'an dan hadits, Islam memperkenalkan konsep relasi antara laki-laki dan perempuan sebagai bentuk keadilan dan kebajikan sekaligus tujuan dari syari'at Islam. Berikut ayat al-Qur'an yang menerangkan kedua konsep tersebut;

33 Hudan Mudaris, "Diskursus Kesetaraan Gender dalam Perspektif Hukum Islam; Menuju Relasi Laki-Laki dan Perempuan Yang Adil Dan Setara," YinYang 4, no. 2 (2009): 10.

34 Muhammad Fauzinuddin Faiz, "Teori Hermeneutika Al-Qur'an Nashr Hamid Abu Zayd dan Aplikasinya Terhadap Wacana Gender dalam Studi Hukum Islam Kontemporer," Al-Ahwal 7, no. 1 (2015): 25.

35 Matlaul Irfan, "Telaah Kritis Atas Pemikiran Gerakan Gender dalam Pandangan Fiqih," Ta'dib 17, no. 2 (2019): 82.

36 Atik Wartini, "Tafsir Feminis M.Quraish Shihab: Telaah Ayat-Ayat Gender dalam Tafsir al-Misbah," Palastren 6, no. 2 (2013): 474.

${ }^{37}$ Meiliarni Rusli, "Konsep Gender dalam Islam,” Kafa ab: Journal of Gender Studies 1, no. 2 (July 12, 2011): 155-56, https://doi.org/10.15548/jk.v1i2.75. 
"Sesunggubnya Allah menyuruh (kamu) berlaku adil dan berbuat kebajikan, memberi kepada kaum kerabat, dan Allah melarang dari perbuatan keji, kemunkaran dan permusuban. Dia memberi pengajaran kepadamu agar kamu mengambil pelajaran.” (QS. Al-Nahl [16]: 90).

Dari ayat di atas, Peran Laki-Laki dan Perempuan mempunyai hak dan kewajiban yang sama sebagai khalifah atau wakil Tuhan di muka bumi. Tidak ada pelarangan dalam ayat alQur'an atau hadits untuk membatasi peran perempuan untuk aktif di berbagai macam profesi. Seperti kata Syekh Rifa'ah Rafi' atTahtawi (1801-1873) yang dikutip oleh Nasr Hamid Zayd tentang perempuan yang berpendidikan; “Turunnya kehormatan perempuan tidak disebabkan oleh keterbukaan ataupun ketertutupan (aurat), tetapi bersumber pada pendidikan yang baik ataupun yang buruk". 38

Dalam ayat yang lain, disebutkan bahwa prinsip egalitarian yakni persamaan antar manusia, baik antara laki-laki dan perempuan maupun antar suku, budaya dan agama, menjadi salah satu tema sentral sekaligus prinsip pokok ajaran Islam (Q.S AlHujurat: 13). ${ }^{39}$ Sekali lagi, makna dari ayat tersebut memberikan gambaran tentang kesetaraan dalam Islam, baik secara spiritual ataupun sosial.

\section{Pemikiran Nasr Hamid Abu Zayd tentang Perempuan dalam Islam}

Berpikir bebas dan berijtihad, sepertinya sudah merupakan nutrisi bagi kehidupan Nasr Hamid Abu Zayd. Tidak ada yang mampu membelenggu kebebasan berpikirnya. Dia tidak rela, apabila al-Qur'an dan hadits dijadikan senjata untuk menyenangkan kepuasan satu kelompok dan menindas kelompok yang lainnya. Al-Qur'an sebagai firman Allah mestinya dapat

38 Zayd, Dekonstruksi Gender: Kritik Wacana Perempuan Dalam Islam, 156.

39 Sarifa Suhra, "Kesetaraan Gender dalam Perspektif Al-Qur'an dan Implikasinya Terhadap Hukum Islam,” . . Volume. 13 (2013): 374. 
berdialog dan menjawab serta merespons situasi, kapan pun dan di mana pun persoalan itu muncul. Sudah menjadi tugas manusia sebagai author untuk melakukan pembacaan yang produktif (alqiraah al-muntijah), bukan hanya sekedar pembacaan yang berulangulang (al-qiraah al-mutakarrirah), sehingga melahirkan pemikiran yang dapat memanusiakan orang, bukan pemikiran yang dispotis dan sadis.

Berdasarkan persoalan di atas, menurut Nasr Hamid Abu Zayd perlu adanya suatu metodologi baru dalam membaca alQur'an, yaitu dengan melihat aspek-aspek di luar dari teks alQur'an (sosio-kultural) dan pendekatan kebahasaan/linguistik (alManhaj al-Tahlil al-Lugawi)/(Fonologi, Morfologi, Sintaksis dan Semantik). Pada dasarnya, pemikiran Nasr Hamid Abu Zayd ini tidaklah murni dari pemikirannya sendiri. Pemikirannya tersebut banyak dipengaruhi oleh gurunya, yaitu Amin al-Khuli yang dikenal sebagai pemikir dan menjadi peletak pertama metode sastra atau linguistik dalam kajian al-Qur'an. ${ }^{40}$

Berangkat dari model pemikiran yang "merugikan" atau bahkan menindas orang atau kelompok yang lain dan bahkan cenderung distorsif, Nasr Hamid Abu Zayd merasa terpanggil untuk ikut berjihad dan berijtihad, termasuk dalam masalah ketertindasan kaum perempuan yang telah menimbulkan relasi lakilaki dan perempuan yang pincang dan bersifat subordinatif. Ada dua tema yang menjadi pokok pembahasan Nasr Hamid Abu Zayd, yaitu kepemimpinan perempuan dan konsep ajaran Nasr Hamid Abu Zayd tentang Islam. Pertama, Kepemimpinan Perempuan, menjadi salah satu isu yang tidak pernah surut dalam diskursus ke-Islaman. Begitu pula Nasr Hamid Abu Zayd yang menyoroti tentang persoalan ketidak adilan gender seperti kepemimpinan perempuan, hak menjatuhkan talak bagi perempuan, hak waris, perempuan menjadi hakim, hijab, aurat, dan

${ }^{40}$ Fikri Hamdani, "Teori Interpretasi Nasr Hamid Abu Zayd," Farabi 13, no. 1 (2016): 30-45. 
lain sebagainya. Belum lagi persoalan tentang keluarnya Adam dari surga yang telah membentuk pandangan yang misoginik (perempuan dilukiskan sebagai makhluk pembawa sial) terhadap perempuan.

Pada sisi lain, dalam bahasa Arab muncul pembedaan antara mudzakar (maskulin) dan muanats (feminin). ${ }^{41} \mathrm{Hal}$ ini berimplikasi pada perlakuan terhadap perempuan yang dianggap sebagai 'orang lain' dan minoritas sehingga kepentingannya bisa ditekan dan mereka masuk dalam perangkap 'proteksi' atau dominasi laki-laki. Diantara kesalahan dalam memahami teks adalah kesalahan dalam memahami konteks sebuah ayat. Ayat yang muncul dalam konteks deskriptif (al-washf al-qurani), tetapi dianggap tasyri', yaitu ayat tentang kepemimpinan (qawamah) laki-laki atas perempuan (Qs. An-Nisa:34) yang berdampak pada model kewenangan laki-laki untuk menghukum perempuan dengan cara 'mendiamkan', pisah ranjang, sampai memukul dalam rangka mendidik kaum perempuan.

Menurut Nasr Hamid Abu Zayd, ayat di atas sebenarnya ingin mengungkap bahwa 'ketetapan' tersebut hanya merupakan pendeskripsian tentang perbedaan ekonomi dan sosial yang terjadi di antara manusia, yaitu perbedaan-perbedaan yang disebabkan oleh hukum-hukum perubahan sosial, atau oleh hukum-hukum yang muncul sesuai dengan kondisi wacana al-Qur'an pada jalan dan hukum ilahi yang bersifat sosiologi. Hal tersebut bertujuan untuk memberikan nasihat dan pelajaran.

Dari penjelasan di atas, qawwamah bukan suatu tasyri', karena ia hanya merupakan deskripsi atas suatu kondisi, dan pelebihan laki-laki atas perempuan bukan merupakan ketetapan ilahi. Karena ia hanya merupakan persaksian atas realitas yang harus diubah demi mewujudkan kesetaraan dan keadilan yang fundamental. Kompleksnya hubungan masyarakat saat ini, menyebabkan

${ }^{41}$ M. Arfan Mu'ammar, Abdul Wahid Hasim dkk, Studi Islam Perspektif Insider/Outsider, 207. 
problem tentang hak dan kewajiban perempuan menjadi lebih luas, yakni menyangkut dimensi sosial, kultural, dan intelektual di dalam seluruh struktur kemasyarakatan tidak terkecuali dalam masyarakat Arab-Islam hari ini. ${ }^{42}$ Sehingga apakah wacana itu bersifat politik ataupun sosial, hasilnya sama saja, diskriminasi individu, baik kaum laki-laki maupun perempuan dan pemaksaan terhadapnya.

Dalam kasus ini terjadilah pemaksaan terhadap perempuan dan anak-anak secara bersamaan. Namun, yang perlu dicermati menurut Nasr Hamid Abu Zayd ialah penyebab hal tersebut, yakni kontribusi laki-laki dalam pemenuhan kebutuhan hidup, bukan karena derajat laki-laki yang memang superior dan perempuan yang imperior. Hal serupa telah disampaikan oleh Nasr Hamid Abu Zayd. Dia mengemukakan bahwa pada zaman modern seperti sekarang ini karena perubahan yang berpengaruh pada ruang lingkup sosial dan institusi yang kemudian menjalar ke tataran struktur sosial yang berkembang di masyarakat. ${ }^{43}$

Kedua, konsep Nasr Hamid Abu Zayd tentang ajaran Islam. Berbeda dengan ilmu sosial yang ditawarkan oleh Marxisme dalam masalah kapitalisme, yang menyebutkan bahwa penindasan perempuan diperlukan karena mendatangkan keuntungan. Misalnya, eksploitasi perempuan dalam rumah tangga akan membuat buruh laki-laki di pabrik lebih produktif, perempuan juga berperan dalam reproduksi buruh murah, sehingga memungkinkan harga tenaga kerja lebih murah (menguntungkan kapitalisme), dan masuknya perempuan sebagai buruh dengan upah lebih rendah menciptakan buruh cadangan. Berdasarkan tiga gagasan yang dibawa oleh Marxisme tersebut, telah menimbulkan ketidaksetaraan dan ketidakadilan terhadap gender. Sebab dalam Islam sendiri mengajarkan kepada umat manusia bagaimana bersikap adil dan benar terhadap seluruh umat manusia. Islam juga

42 Zayd, Dekonstruksi Gender: Kritik. Wacana Perempuan dalam Islam, 155.

${ }^{43}$ Imam Syafi'i, "Gender Mainstreaming Analisa Metodologi Studi Gender Pemikiran Nasr Hamid Abu Zayd dan Amina Wadud," Vicratina 2, no. 1 (2017): 16. 
hadir untuk menyelamatkan perempuan dari penindasan dan penghinaan yang menyebabkan penderitaan. Islam datang untuk meluruskan pengertian-pengertian yang salah, melaksanakan hukum dan memulihkan kehormatan kaum perempuan.

Secara sederhana, proyek kajian Nasr Hamid Abu Zayd adalah mencoba membongkar konsep keyakinan. Ia percaya, banyak teks yang hanya diyakini tanpa upaya pemahaman yang konkret, keimanan tanpa landasan. Sebenarnya Abu Zayd mencoba perpijak pada dua sasaran utama ketika berhadapan dengan teksteks Quran.: pertama, Ia mencoba meletakkan status tekstualitas AlQuran; kedua, untuk menentukan suatu pemahaman yang obyektif terhadap pemahaman teks tersebut. Abu Zayd memandang dua sasaran itu, merupakan satu kesatuan yang tak terpisahkan, satu sisi dari sekeping dua mata uang. ${ }^{44}$ Seperti yang telah disinggung di awal, dalam kehidupan nyata, kedudukan perempuan dan laki-laki masih menyisakan banyak problem. Sebab ditemukan berbagai ketimpangan di berbagai ranah kehidupan sosial, budaya hingga politik, yang laki-laki lebih banyak diuntungkan sementara perempuan selalu dinomorduakan, untuk tidak mengatakan dirugikan. Itu terjadi salah satunya disebabkan adanya sistem budaya patriarkhi yang lebih banyak menempatkan perempuan sebagai objek daripada subjek.

Bagi mereka yang kurang peka dengan kenyataan bahwa patriarki adalah kelaliman (despotism) dan secara moral menyerang keadaan masyarakat. Sebagai sebuah institusi, patriarki telah berimplikasi dan berkonsekuensi negatif. Pertama, menghapuskan peran perempuan sebagai agen Tuhan (khalifah Allah); ia memarjinalkan perempuan; kedua, secara signifikan menghilangkan potensi sebagai makhluk yang benar-benar pasrah/tunduk kepada Tuhan. Penafsiran atas teks-teks keagamaan tidak akan berhenti seiring dengan realitas kemanusiaan yang senantiasa berubah. Teks

44 Aris Baidowi, "Dekontruksi Gender dalam Kitab Dawâirul Khaufi (Qirâah Fî Khitâbil Mar'ah) Karya Nasr Hamid Abu Zayd)," Munaąah 3, no. 2 (2011): 475.

80| TAJDID vol. 19, No. 1, Januari - Juni 2020 
tidak bisa lepas dari konteksnya. Teks al-Qur'an memiliki konteks kesejarahan, begitu juga tradisi-tradisi tafsir keagamaan. Karenanya Nasr Hamid Abu Zayd memandang perlunya pembacaan teks dengan pembacaan kontekstual (al-qiraat al-siyaqiyyah) agar ditemukan karakter aslinya sebelum adanya keterlibatan para penafsir dalam mengikis makna aslinya hingga turut menghegemoni nalar-nalar pemaknaan tertentu, termasuk pemaknaan teks-teks yang berhubungan dengan laki-laki dan perempuan.

Dalam upaya menafsirkan ayat-ayat al-Qur'an melalui metode kontekstual, harus dicatat juga bahwa pendekatan kontekstual ini, sebenarnya bukanlah pendekatan murni atau baru, melainkan pengembangan dari teori-teori ushul al-fiqh, 'ulum alQur'an, khususnya yang membahas mengenai asbab al-nuгul, nasikhmansukh hingga ilmu kebahasaan. Lalu Nasr Hamid Abu Zayd melihat masalah ini lebih menggambarkan bahwa pemahaman di atas tidak lepas dari kontruksi sosial budaya orang Arab sebelum Islam yang cenderung bias gender dan patriarkal. Oleh sebab itu, pembacaan kontekstual dapat diterapkan terhadap wacana perempuan dalam Islam, khususnya mengenai isu-isu gender yang dapat terwujud secara maksimal, baik dalam level akademisi maupun aksi. ${ }^{45}$ Sehingga Islam mampu mengatasi problematika tersebut.

\section{Penutup}

Nasr Hamid Abu Zayd merupakan seorang cendikiawan sekaligus pemikir asal Mesir yang sangat penting dalam mengkaji isu-isu ketidakadilan gender. Feminitas dan dekontruksi perempuan dalam studi pemikiran Nasr Hamid Abu Zayd, telah melahirkan penafsiran atas teks-teks keagamaan yang tidak akan pernah berhenti seiring dengan realitas kemanusiaan yang

45 Mohammad Muchlis Solichin, "Pendidikan Agama Islam Berbasis Kesetaraan Gender," Tadris 1, no. 1 (2006): 51-52. 
senantiasa berubah. Teks tidak bisa lepas dari konteksnya. Teks alQur'an memiliki konteks historis-sosial, begitu pula dengan tradisi keilmuan tafsir. Karenanya Nasr Hamid Abu Zayd memandang perlunya pembacaan teks dengan pembacaan kontekstual (al-qiraat al-siyaqiyyah) agar ditemukan karakter aslinya sebelum adanya keterlibatan para penafsir dalam mengikis makna aslinya hingga turut menghegemoni nalar-nalar pemaknaan tertentu, termasuk pemaknaan teks-teks yang berhubungan dengan laki-laki dan perempuan. Dengan pembacaan kontekstual inilah, perempuan dapat terlepas dari wacana sektarian-rasialistik dengan segala makna di belakangnya. Sehingga teks-teks keagamaan tidak kehilngan konteks sosialnya, dan dapat menyelesaikan isu-isu sosial, salah satunya isu tentang kesetaraan gender.

\section{Daftar Pustaka}

Baidowi, Ahmad. Memandang Perempuan: Bagaimana al-Quran dan Penafsir Modern Menghormati Kaum Hawa. Bandung: Marja, 2011.

Baidowi, Aris. "Dekonstruksi Gender dalam Kitab Dawâirul Khaufi (Qirâah Fî Khitâbil Mar'ah) Karya Nasr Hamid Abu Zayd)." Muwazah 3, no. 2 (2011).

Bdws, Muzayyin. "Kritik Terhadap Konsep Tanzil Nasr Hamid Abu Zayd Dan Implikasinya Terhadap Status Al-Qur'an." TAJDID: Jurnal Ilmu Ushuluddin 17, no. 2 (June 15, 2019): 153-80. https://doi.org/10.30631/tjd.v17i2.69.

Bidayah, Afifah. "Riffat Hassan dan Wacana Baru Penafsiran." KALIMAH 11, no. 2 (2013): 16.

Efendy, Rustan. "Kesetaraan Gender dalam Pendidikan." Jurnal Al-Maiyyah 07, no. 2 (2014): 24.

Faiz, Muhammad Fauzinuddin. “Teori Hermeneutika Al-Qur'an Nashr Hamid Abu Zayd dan Aplikasinya Terhadap Wacana Gender dalam Studi Hukum Islam Kontemporer." Al-Ahwal 7, no. 1 (2015): 40. 
Fakih, Mansour. Analisis Gender dan Transformasi Sosial. Yogyakarta: Pustaka Pelajar, 2013.

Fauziyah, Yayuk. "Menyingkap Kuasa Maskulinitas Di Balik Tabir Feminitas Wanita Jawa." Ulumuna 12, no. 1 (November 5, 2017): 183-200. https://doi.org/10.20414/ujis.v12i1.397.

Hamdani, Fikri. "Teori Interpretasi Nasr Hamid Abu Zayd." Farabi 13, no. 1 (2016): 16.

Hamka. Buya Hamka Berbicara tentang Perempuan. Jakarta: Gema Insani, 2014.

Husni, Muhammad. "Kekerasan Terhadap Perempuan: Analisis Gender dalam Taoisme Islam” 10, no. 2 (2016): 7.

Iqbal, Mahathir Muhammad. "Diskursus Gender dalam Pendidikan Islam.” Analisis 15, no. 1 (2015): 22.

Irfan, Matlaul. "Telaah Kritis atas Pemikiran Gerakan Gender dalam Pandangan Fiqih.” Ta'dib 17, no. 2 (2019).

M. Arfan Mu'ammar, Abdul Wahid Hasim dkk,. Studi Islam Perspektif Insider/Outsider. Yogyakarta: IRCiSoD, 2013.

Mernissi, Fatima. Ratu-Ratu Islam Yang Terlupakan. Bandung: Mizan, 1996.

Mudaris, Hudan. "Diskursus Kesetaraan Gender dalam Perspektif Hukum Islam; Menuju Relasi Laki-Laki dan Perempuan Yang Adil Dan Setara." YinYang 4, no. 2 (2009): 10.

Muqoyyidin, Andik Wahyun. "Wacana Kesetaraan Gender: Pemikiran Islam Kontemporer tentang Gerakan Feminisme Islam.” Jurnal Al-Ulum 13, no. 2 (2013): 22.

Mutawakkil, M. Hajir. "Keadilan Islam dalam Persoalan Gender." KALIMAH 12, no. 1 (March 5, 2014): 67. https://doi.org/10.21111/klm.v12i1.219.

Nezar Patria \& Andi Arief. Antonio Gramsci: Negara Dan Hegemoni. Yogyakarta: Pustaka Pelajar, 2015.

Novianti, Ida. "Dilema Kepemimpinan Perempuan dalam." YinYang 3, no. 2 (2008): 5. 
Asep Saepullah

Rohmaniyah, Inayah. Gender dan Kontruksi Patriarki dalam Tafsir Agama. UIN Sunan Kalijaga Yogyakarta: Suka Press, 2020.

Rusli, Meiliarni. "Konsep Gender dalam Islam.” Kafa ab: Journal of Gender Studies 1, no. 2 (July 12, 2011): 151. https://doi.org/10.15548/jk.v1i2.75.

Solichin, Mohammad Muchlis. "Pendidikan Agama Islam Berbasis Kesetaraan Gender." Tadris 1, no. 1 (2006): 10.

Suhra, Sarifa. "Kesetaraan Gender dalam Perspektif Al-Qur'an dan Implikasinya Terhadap Hukum Islam.” . . Volume. 13 (2013): 22.

Suryorini, Ariana. "Menelaah Feminisme dalam Islam." Sawwa: Jurnal Studi Gender 7, no. 2 (May 15, 2012): 21. https://doi.org/10.21580/sa.v7i2.647.

Syafi'i, Imam. "Gender Mainstreaming Analisa Metodologi Studi Gender Pemikiran Nasr Hamid Abu Zayd dan Amina Wadud." Vicratina 2, no. 1 (2017).

Wartini, Atik. "Tafsir Feminis M.Quraish Shihab: Telaah AyatAyat Gender dalam Tafsir al-Misbah." Palastren 6, no. 2 (2013): 22.

Zayd, Nasr Hamid Abu. Dekonstruksi Gender: Kritik Wacana Perempuan dalam Islam. Yogyakarta: Samha, 2003.

Zubeir, Rusdi. "Gender dalam Perspektif Islam." An Nisa'a 7, no. 2 (2012): 15. 